\title{
ETIKA PENDIDIK PERSPEKTIF IMAM AL-NAWAWÎ
}

\author{
Salminawati \\ Pascasarjana UIN Sumatera Utara \\ Jl. IAIN No. 1 Medan, Sumatera Utara, 20232 \\ e-mail: salminawati71@gmail.com
}

\begin{abstract}
Abstrak: Kebijakan pendidikan nasional menghendaki para pendidik di Indonesia harus memiliki empat kompetensi, di antaranya adalah kompetensi kepribadian. Pendidikan nasional juga menegaskan urgensi penanaman karakter oleh pendidik terhadap peserta didik, sehingga para pendidik pun dituntut memiliki karakter yang telah ditetapkan. Artikel ini mengkaji tinjauan fukaha terhadap etika pendidik dalam Islam. Di antara fukaha di dunia Islam, Imam al-Nawawî telah memberikan ulasan tentang etika pendidik dalam Islam. Berdasarkan analisis isi terhadap karya Imam al-Nawawî, ditemukan bahwa seorang pendidik Muslim dituntut memiliki etika yang harus dipahami dan diamalkan dalam proses pembelajaran, yang terdiri atas etika pendidik dari aspek kepribadian, etika pendidik dari aspek kegiatan ilmiah, dan etika pendidik dari aspek penyampaian pembelajaran. Artikel ini telah menegaskan bahwa khazanah Islam tentang etika pendidik sangat kaya, dan harus diaktualisasikan dalam dunia pendidikan Islam di Indonesia.
\end{abstract}

\begin{abstract}
Teacher's Ethic in the Perspective of Imam al-Nawawî's Thought. National education policies require educators in Indonesia to have four competencies; among of it is personality competences. National education reiterated the urgency of the character building by educators to students, so that the educators were required to have a character that has been decided. This article examines the Jurists review toward educators' ethics in Islam. Among of jurists in Islamic world, Imam al-Nawawî has given reviews on educators' ethics in Islam. Based on a content analysis of Imam al-Nawawî work, it was found that a Muslim educators are required to have ethics that must be understood and practiced in the learning process, which consists of educators ethics from personality aspects, educators ethics from scientific activity aspect, and educators ethics from learning delivery aspects, This article has been asserted that the Islamic literatures about the educators ethics is very much, and must be actualized in Islamic education in Indonesia.
\end{abstract}

Kata Kunci: al-Nawawî, etika, pendidik, kepribadian, kegiatan ilmiah, pembelajaran 


\section{Pendahuluan}

Pendidikan Islam sebagai sistem pendidikan yang didasari ajaran Islam bertujuan untuk mewujudkan seorang Muslim ideal, yakni seorang yang ahli pikir dan zikir. Pendidikan Islam sendiri terdiri atas enam sumber, yaitu al-Qur'an, Sunnah, kata-kata sahabat, kemaslahatan umat, tradisi atau adat kebiasaan masyarakat dan hasil pemikiran para ahli dalam lingkup pemikiran Islam. Keenam sumber pendidikan Islam tersebut didudukkan secara herarkis. Artinya, rujukan pendidikan Islam harus diawali dari Alquran dilanjutkan pada sumbersumber berikutnya. ${ }^{1}$

Dalam proses pembelajaran, sosok seorang pendidik mendapatkan perhatian khusus di lembaga-lembaga pendidikan. Ada beberapa ungkapan para ulama terdahulu tentang pentingnya belajar langsung dari seorang pendidik. Ibn Khaldûn (w. 1406) dalam kitab Muqaddimahnya ${ }^{2}$ berkata "barang siapa yang tidak belajar langsung dasar-dasar ilmu dari seorang ulama, maka kesimpulan-kesimpulan yang diyakininya dalam banyak masalah yang sulit sebenarnya hanya dugaan-dugaan." Ungkapan lain tentang pentingnya sosok seorang pendidik juga tergambar dalam kalimat berikut ini, "barang siapa yang memasuki suatu bidang ilmu seorang diri, ia akan keluar juga seorang diri." Artinya, barang siapa yang mempelajari ilmu tanpa pendidik, ia akan keluar tanpa ilmu. Karena ilmu adalah sebuah bidang keahlian yang butuh pada ahlinya, maka harus dipelajari dari ahlinya yang mumpuni. ${ }^{3}$

Pendidik di era modern tidak banyak yang mempersepsikan dirinya sebagai pengemban amanat yang suci dan mulia, dan mengembangkan nilai-nilai multipotensi peserta didik. Bahkan terkadang muncul sifat egoisme bahwa ketika seorang pendidik akan melakukan tugasnya termotivasi oleh sifat yang materialis dan pragmatis yang tidak lagi dimotivasi oleh rasa keikhlasan dan panggilan untuk mengembangkan fitrah peserta didiknya. Pendidik kurang memosisikan dirinya sebagai seorang figur teladan yang perlu ditiru. Seorang figur atau tokoh pendidik itu perlu dilacak dan diketahui, karena dengan jelasnya siapa tokoh atau pendidik itu, maka akan memberikan kontribusi yang positif terhadap peserta didiknya. Kekhasan keilmuannya akan mengalir kepada para peserta didiknya. ${ }^{4}$

Artikel ini memaparkan bagaimana etika seorang pendidik dalam mengemban amanahnya sebagaimana dirumuskan oleh Imam al-Nawawî dalam Muqaddimah kitabnya al-Majmû' Syarh al-Muhazzab li al-Syîrâzî. Kitab tersebut adalah kitab fikih yang menjelaskan hukum-hukum atau syariat bagi umat Islam. Namun dalam mMuqaddimah-nya, ia memaparkan tentang etika yang harus dimiliki oleh seorang pendidik dalam aktivitasnya menuntut dan mengajarkan ilmu. Hal ini membuktikan bahwa betapa pentingnya kedudukan etika

${ }^{1}$ Hasan Langgulung, Azas-Azas Pendidikan Islam (Jakarta: Pustaka al-Husna, 1987), h. 43. ${ }^{2}$ Abd al-Rahmân Ibn Khaldûn, Muqaddimah, Jilid III (Beirut: Dâr al-Jayl, t.t.), h. 551.

${ }^{3}$ Bakar ibn 'Abdullah Abu Zaid, Hilyat Thalibi al-'Tlmi (Kairo: Dâr al-'Aqîdah, 1426 H), h. 73.

${ }^{4}$ Usman, "Karakter Pendidik di Era Klasik dan Modern: Sebuah Upaya Menuju Pendidik yang Berkualitas," dalam Suwito dan Fauzan (ed.), Sejarah Sosial Pendidikan Islam (Jakarta: Kencana, 2005), h. 4-5. 
dibandingkan dengan urusan-urusan lain. Kajian etika ini diharapkan dapat menjadi inspirasi dan petunjuk bagi orang yang ingin memperoleh keberkahan hidup, yaitu dengan usaha mengajarkan ilmu.

Secara khusus, artikel ini mengkaji etika akademik pendidik menurut Imam al-Nawawî ditinjau dari aspek kepribadiannya, kegiatan ilmiahnya, dan etika dalam menyampaikan pelajarannya. Secara metodologis, artikel ini menggunakan pendekatan sejarah (historical approach). Salah satu jenis penelitian sejarah adalah penelitian biografis, yaitu penelitian terhadap kehidupan seseorang dalam hubungannya dengan masyarakat, sifat-sifat, watak, pengaruh pemikiran dan idenya serta pembentukan watak tokoh tersebut selama hidupnya. ${ }^{5}$ Untuk menganalisis data, digunakan analisis isi (content analysis) yang dimaksudkan untuk melakukan analisis terhadap makna-makna yang terkandung dalam keseluruhan gagasan Imâm al-Nawawî. Berdasarkan isi yang terkandung dalam gagasan itu, dilakukanlah pengelompokan terhadap pemikiran-pemikirannya yang disusun secara logis.

\section{Biografi Imam al-Nawawî}

Abû Zakariyâ Muhy al-Dîn ibn Syarf al-Nawawî (w. 1278), yang lebih dikenal dengan Imam al-Nawawî, adalah salah satu ulama yang masyhur dengan keilmuannya dalam sejarah Islam. Ia hidup pada masa Dinasti Mamlûk, dan bersamaan pada waktu itu juga hampir berakhirnya masa pemerintahan Dinasti Ayyubîyyah, tepatnya pada masa pemerintahan Sultan Baybars (Babiris) Malik al-Zâhir (w. 1277). ${ }^{6}$

Imam al-Nawawî dilahirkan di kota Nawa7 pada minggu kedua bulan Muharram

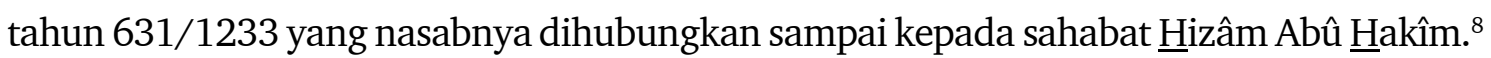
Nama lengkapnya adalah Abû Zakariyâ Yahyâ ibn Syaraf al-Dîn ibn Murriyun al-Nawawî. ${ }^{9}$ Ia diberi gelar Muhyî al-Dîn (yang menghidupkan agama), akan tetapi ia sangat membenci gelar ini karena ketawadukannya. Ayahnya, Syaraf ibn Murriyun (w. 1286), seorang zahid yang warak terkenal dengan kesalehannya berprofesi sebagai pedagang di kota Nawâ dan

${ }^{5}$ Sartono Kartodirjo, Pendekatan Ilmu Sosial dalam Metodologi Sejarah (Jakarta: Gramedia Pustaka Utama, 1993), h. 77.

${ }^{6}$ Mahmud Syâkir, al-Târîkh al-Islâmî al-Ahdi al-Mamlukî, Jilid IV (Beirut: al-Maktabah alIslâmî, 1421 H), h. 12.

${ }^{7}$ Nawâ adalah sebuah kota kecil di pedalaman Damaskus, Ibn al-Aththâr mengatakan bahwa tempat kelahiran Imâm al-Nawawî adalah sebuah kampung di kota Harran dan menempati rumah Nabi Ayyûb as. Di kota tersebut juga terdapat kuburan Sam ibn Nuh. Ibn al-Aththâr, Tuhfah ath-Thâlibîn li Ibn al-Aththâr, Vol. III (Beirut: Dâr Ihyâ' al-Turâts, 1989), h. 35.

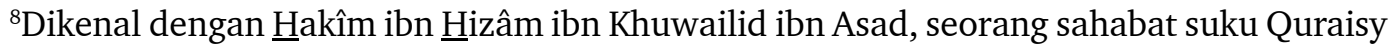
keponakan Khadîjah Umm al-Mukminîn (w. 54/673) seorang wanita pembesar di kalangan Quraisy pada masa Jahiliyyah dan Islam.

${ }^{9}$ Kata al-Nawawî dilekatkan pada namanya untuk menandakan ia berasal dari kota Nawâ. Muhammad 'Abd al-Razzâq al-Zabîdî, Tâj al-Arûs min Jawâhir al-Qâmûs, Vol. I (Beirut: Dâr Ihyâ' al-Turâts, 1984), h. 244. 
memiliki toko yang besar di kota tersebut. Imam al-Nawawî sehari-hari menemani ayahnya di toko sambil menghapal al-Qur'an.

Riwayat pendidikan Imam al-Nawawî dimulai dari pendidikan dasar yang selain langsung di bawah bimbingan ayahnya, ia juga menempuh pendidikan formal di beberapa kuttâb yang ada di kota Nawa. Pada tahun 649/1251 bersama ayahnya, Imam al-Nawawî melakukan lawatan ilmiah (rihliah al-ilmîyyah) ke Damaskus untuk melanjutkan pendidikannya dan usianya pada waktu itu adalah 18 tahun. ${ }^{10}$

\section{Hakikat Etika dalam Kajian Filsafat}

Secara etimologi, etika berasal dari kata Yunani ethos dalam bentuk tunggal yang mempunyai banyak arti, tempat tinggal yang biasa, padang rumput, kebiasaan, adab, akhlak, watak, perasaan, dan sikap cara berpikir. Dalam bentuk jamak (ta etha) berarti adat kebiasaan. Arti terakhir inilah yang menjadi latar belakang bagi terbentuknya istilah etika dalam filsafat moral. Jadi, etika berarti ilmu tentang apa yang biasa dilakukan atau ilmu tentang adat kebiasaan. ${ }^{11}$

Etika juga disepadankan dengan kata moral atau dalam bahasa latin, mos yang untuk jamaknya mores, yang berarti adab, kesusilaan, sopan santun, dan tradisi. Sedangkan dalam arti luas, etika adalah semua orientasi bagi usaha manusia untuk menjalani hidup di dunia. ${ }^{12}$ Meskipun sama maknanya yang terkait dengan baik-buruk tindakan manusia, etika dan moral memiliki perbedaan pengertian. Jika moral lebih cenderung pada pengertian "nilai baik dan buruk" dari setiap perbuatan manusia, sementara etika mempelajari tentang baik dan buruk. Dengan kata lain, etika berfungsi sebagai teori dari perbuatan baik dan buruk (ethic atau ilmu al-akhlâq) dan moral (akhlâq) adalah praktiknya. ${ }^{13}$

Dalam perspektif Islam, etika dapat dimaknakan dengan istilah akhlak, meskipun tidak didapati secara eksplisit dalam al-Qur'an, yang ditemukan hanyalah bentuk mufrad (tunggal) kata tersebut yaitu khuluq yang terdapat dalam Q.S. al-Qalam/68: 4, dan sesungguh-

\footnotetext{
${ }^{10}$ Damaskus pada masa itu merupakan pusat berkumpulnya para ulama dan para penuntut ilmu dari berbagai negeri Islam dan seorang penuntut ilmu dianggap belum sempurna ilmunya jika belum mengunjungi kota Damaskus. Damaskus termasuk salah satu kota penting untuk mengkaji berbagai disiplin ilmu baik itu ilmu syariah, bahasa dan ilmu-ilmu yang sangat terkenal pada masa itu. Sejarah dinamika intelektual tentang kota Damaskus secara terperinci dapat dibaca dalam Târîkh Dimasyq, karya Ibnu 'Asâkir yang ditulis dalam 80 jilid berisi tentang biografi para ulama, sastrawan, penyair dan pejabat pemerintah serta tokoh-tokoh yang pernah berkunjung ke kota ini atau hanya sekedar singgah. Abî al-Qâsim 'Aly ibn Husain ibn Hibah al-Allâh ibn 'Abd Allâh al-Syâfi'î, dikenal dengan Ibn 'Asâkir (499-571/1105-1175), Târîkh Madînah Dimasyq, ditahqiq oleh Muhibbuddîn Abî Sa'îd (Beirut: Dâr al-Fikr, 1415/1995).

${ }^{11}$ K. Bertens, Etika, Cet. 10 (Jakarta: Gramedia Pustaka Utama, 2007), h. 4.

${ }^{12}$ Frans Magis Suseno, Etika Dasar: Masalah-Masalah Pokok Filsafat Moral (Yogyakarta: Kanisius, 1993), h. 13.

${ }^{13}$ Muhammad Alfan, Filsafat Etika Islam (Bandung: Pustaka Setia, 2011), h. 21.
} 
nya kamu benar-benar berbudi pekerti yang agung. ${ }^{14}$ Secara etimologi, kata akhlâq adalah bentuk jamak dari kata khuluq yang berarti budi pekerti, perangai, tingkah laku dan akhlak (tabiat). Tabiat atau watak muncul karena hasil perbuatan yang diulang-ulang sehingga menjadi biasa. Perkataan akhlak dalam bahasa Indonesia juga sering disebut dengan kesusilaan, sopan santun, dan moral. Kata tersebut mengandung segi-segi persesuaian dengan kata khalqun yang berarti kejadian, yang juga erat hubungannya dengan khâliq yang berarti pencipta, demikian pula dengan kata makhlûqun yang berarti yang diciptakan. ${ }^{15}$

Para filsuf Muslim telah menjelaskan keterkaitan antara etika dengan ilmu pengetahuan. Menurut mereka, etika merupakan salah satu bagian filsafat praktis seperti halnya ekonomi dan politik. Sebagai ilmu praktis, etika merupakan aplikasi dari ilmu-ilmu teoritis atau yang biasanya disebut ilmu pengetahuan ( $\mathrm{ilm}$ ). Dikatakan bahwa etika berkenaan dengan pengetahuan tentang tindakan-tindakan voluntary (sukarela) sejauh mereka mendorong tercapainya kebahagiaan manusia. Dalam bentuk yang sederhana, hubungan ilmu dengan etika dapat diumpamakan dengan hubungan antara pelita dan pejalan kaki. Ilmu kata Nabi Muhammad SAW. adalah cahaya (al-ilm nur) dan tentu cahaya seredup apapun sangat diperlukan oleh pejalan kaki yang sedang melakukan perjalanan tertentu di malam hari yang gelap gulita. ${ }^{16}$

Dengan demikian, kedua aspek tersebut di atas (ilmu dan etika) tidak bisa dipisahkan dalam Islam. Memiliki ilmu saja tidak cukup menjamin seseorang bisa menjadi baik moralnya kalau tindakannya itu tidak didasarkan pada pengetahuan. Sekalipun si pejalan kaki memiliki senter (pelita), tetapi kalau senter itu tidak digunakan, maka keberadaan senter sebagai simbol dari ilmu tersebut tidak ada gunanya. Rasulullah SAW. bersabda dalam hadisnya, "ilmu yang tidak diamalkan seperti pohon yang tidak berbuah, amal tanpa ilmu tidak akan tercapai tujuan yang diharapkan".

\section{Etika Pendidik Ditinjau dari Kepribadian}

Ditinjau dari kepribadian, Imam al-Nawawî menyebutkan bahwa seorang pendidik Muslim harus memiliki etika sebagai berikut. Pertama, dalam mengajar seorang pendidik harus memiliki niat yang tulus semata-mata karena Allah. Mengajar jangan dijadikan sebagai sarana untuk memperoleh hasrat duniawi. Dalam hal ini, ia mengambil contoh seperti untuk mendapatkan uang yang banyak, mendapatkan kehormatan dan kemasyhuran, mendapatkan prestise (gengsi) ataupun untuk sekadar mencari kesibukan di luar rumah semata. Mengajar juga jangan dijadikan sebagai upaya negatif untuk memecah belah persamaan dan persatuan umat sehingga terjadi perselisihan di antara umat. Selanjutnya,

\footnotetext{
${ }^{14}$ Q.S. al-Qalam/68: 4.

${ }^{15}$ A. Mustafa, Akhlak Tasawuf (Jakarta: Pustaka Setia, 1999), h. 11.

${ }^{16}$ Mulyadhi Kartanegara, Nalar Religius: Memahami Hakikat Tuhan, Alam dan Manusia (Jakarta: Erlangga, 2007), h. 120.
} 
ia menjelaskan bahwa hal yang terpenting dalam aktivitas mengajar adalah seorang pendidik itu tidak menodai ilmu dan kegiatan pengajarannya dengan sesuatu yang bersifat ambisius dalam mendapatkan simpati orang yang diajarkannya sehingga orang yang diajarkan menjadi sibuk melayaninya dan menyediakan biaya dan sebagainya, walaupun sebenarnya fasilitas dan pelayanan yang diberikan kepadanya itu merupakan sebuah hadiah yang dianggap tidak merepotkan bagi orang yang memberikannya. Alasan Imam al-Nawawî berpendapat demikian karena adanya ayat dan hadis yang menjelaskan tentang hal yang berkenaan dengan bab "tercelalah orang yang mengajarkan ilmunya dengan tujuan selain dari Allah." ${ }^{\prime 17}$

Kedua, seorang pendidik harus beretika dengan etika yang baik dengan standar penilaiannya adalah sesuai dengan petunjuk hukum Islam dan konsisten dalam menjalankannya. Di antara indikatornya adalah bersifat zuhud dan sederhana dalam mencari kehidupan dunia. Senantiasa menjaga sikap zuhud tersebut dengan menambah kebaikan pada dirinya berupa sikap rendah hati, dermawan, beretika mulia, menebarkan senyum tanpa berlebihan, menyimpan perasaan yang penuh keluh kesah di hadapan orang banyak, bersikap santun, sabar dan menghindarkan diri dari pekerjaan yang membuat diri menjadi hina. Memiliki sikap warak, khusyuk, tenang, tawaduk, patuh, tidak berlebih-lebihan ketika tertawa, dan bercanda merupakan sifat lainnya yang harus ditanamkan pada diri seorang pengajar. Selanjutnya, Imam al-Nawawî juga menjelaskan tentang etika yang berhubungan dengan jasmani juga harus dijaga oleh seorang pendidik (pendidik) di antaranya membersihkan tubuhnya dari kotoran dan bau yang tidak sedap yang dapat mengganggu kenyamanan ketika proses belajar mengajar berlangsung, merapikan janggut bahkan mencukur bulu ketiak dan bulu hidung. ${ }^{18}$

Ketiga, seorang pendidik harus menghindari diri dari penyakit hati seperti sifat asad (dengki), riya', 'ujub, dan ihtiqâr (meremehkan orang lain). Penyakit-penyakit hati tersebut merupakan ujian bagi orang-orang yang berilmu karena penyakit ini menjadikan jiwa orang-orangnya menjadi hina dan rendah. Imam al-Nawawî menawarkan solusi agar terhindar dari penyakit-penyakit hati tersebut. (1) metode dalam menghindari penyakit hasad adalah dengan cara mengenal sedalam-dalamnya hikmah dari kelebihan yang telah Allah tetapkan pada seseorang itu tanpa mengajukan protes ataupun kebencian hikmah yang telah ditetapkan tersebut. Janganlah mencela Allah karena hal tersebutmemasukkan diri ini ke dalam daftar orang yang berbuat maksiat. (2) untuk menghindari penyakit riya', metodenya adalah menyadari bahwa pada hakikatnya manusia itu tidak dapat memberikan manfaat maupun kemudaratan pada dirinya dan bersusah payah untuk menolong orang lain. Selain itu, harus menyadari bahwa sifat riya' sebenarnya membuat letih diri sendiri dan menghapus amal kebaikan dan menghapus rida Allah. (3) metode untuk menghapus sifat 'ujub adalah dengan menyadari bahwa ilmu itu merupakan sebuah kemuliaan yang

\footnotetext{
${ }^{17}$ Al-Nawawî, al-Majmu' Syarah al-Muhazzab (Beirut: Dâr al-Fikr, 1980), h. 54.

${ }^{18}$ Ibid.
} 
Allah titipkan kepada manusia dan segala bentuk pinjaman akan diberikan dan diambil pada waktu yang tidak ditentukan, dan jangan meyakini bahwa ilmu yang dimiliki itu akan selalu tetap berada di hati. Dengan demikian, seorang pendidik harus menyadari bahwa ia bukan pemilik ilmu yang dikuasainya dan tidak pula ada jaminan ia akan tetap memilikinya. (4) metode untuk menghilangkan sifat al-ihtiqâr atau penyakit hati yang suka merendahkan/ meremehkan orang lain dapat dihilangkan dengan cara menyadari bahwa sesungguhnya tidak ada orang yang lebih mulia di sisi Allah kecuali orang yang bertakwa. ${ }^{19}$

Keempat, seorang pendidik harus selalu menghiasi lidahnya dengan perkataan yang mengandung pujian dan kepasrahan kepada Allah, dan menghiasinya dengan zikir dan doa-doa dan etika yang berhubungan dengan syariat. ${ }^{20}$ Seorang pendidik yang memiliki karakter yang baik adalah seorang pendidik yang menyadari bahwa ilmu yang dimilikinya adalah berasal dari Allah, sehingga menyadari dirinya untuk tidak sombong dengan ilmu yang dikuasainya. Para ilmuwan Muslim di Abad Pertengahan memadukan antara ilmu sains dan agama. Keduanya memiliki keterkaitan erat. Pada masa itu tidak terdapat dikotomi ilmu. Setiap penemuan ilmiah berawal dari pemahaman mereka terhadap ayatayat Allah. Tasbih atau pujian yang dipanjatkan kepada Allah senantiasa mereka panjatkan selama mereka mengarungi ilmu pengetahuan dengan bimbingan Allah. Ditambah dengan zikir terhadap ayat-ayat Allah, baik yang termaktub (alam) maupun berupa dalil naqli, semuanya dipadukan dalam zikir dan pikir, sehingga iman dan akal mereka tunduk pada Maha Kuasanya Allah dan Maha Luas Ilmu-Nya.

Kelima, seorang pendidik harus senantiasa menyadari dirinya selalu dalam pengawasan Allah SWT. baik dalam kondisi sepi (sendiri) maupun ramai, selalu menjaga keistiqamahan amal dengan rajin membaca al-Qur'an dan melaksanakan salat dan puasa sunnah dan amalan-amalan sunah lainnya. Selalu mengutamakan Allah dalam setiap aktivitas kehidupan berpegang teguh kepada Allah, dan berserah diri atas segala urusannya kepada Allah semata. ${ }^{21}$

Keenam, seorang pendidik tidak boleh merendahkan ilmu. Artinya, ia tidak pergi untuk mengajarkan ilmu ke suatu tempat dengan tujuan agar orang memuliakannya dan belajar kepadanya meskipun para pelajar itu adalah orang yang kaya. Tetapi seharusnya seorang pendidik itu menjaga wibawa ilmu tersebut dari hal-hal yang demikian sebagaimana yang dilakukan oleh ulama-ulama Salaf dalam menjaga ilmu mereka. Kisah-kisah mereka dengan para khalifah dan para pembesar lainnya sungguh sangat banyak dan terkenal. ${ }^{22}$

\footnotetext{
${ }^{19} I$ Ibid., h. 55.

${ }^{20} \mathrm{Ibid}$.

${ }^{21}$ Ibid.

${ }^{22}$ Seorang raja menyerahkan anak laki-lakinya kepada seorang pendidik dan berkata kepadanya, "didiklah ia sebagaimana engkau mendidik anakmu sendiri." Setelah beberapa tahun menjalani pendidikan, sang pangeran tidak mengalami kemajuan, sementara anak sang pendidik prestasi dan ilmu pengetahuannya mengungguli anak sang raja. Raja menyalahkan pendidik dan menuduhnya telah berbuat tidak adil dalam mengajar, kemudian sang pendidik menjawab "Yang Mulia, saya telah mengajar dengan adil dalam semua hal, tetapi setiap orang memiliki kemampuan yang berbeda-
} 
Di sisi lain, Imam al-Nawawî menjelaskan bahwa seorang pendidik boleh tidak bersikap seperti pernyataan di atas, jika kondisinya darurat atau tuntutan kemaslahatan (kebaikan) yang lebih besar ketimbang mafsadat (kerugian) merendahkan ilmunya. Hal ini juga didasarkan pada informasi yang didapati dari sebagaian ulama Salaf yang melakukan hal tersebut. ${ }^{23}$

Seorang pendidik yang dengan ilmunya memiliki niat ingin memperkaya diri, maka sesungguhnya ia menjauhkan dirinya dari keberkahan ilmu dan kemuliaan. Pada masa modern ini terkadang didapati seorang pendidik yang enggan mengajar di tempat yang gajinya dibayar murah, karena menurutnya gaji yang diperolehnya tidak sebanding dengan ilmu yang dimilikinya. Bahkan lebih parahnya lagi, demi memperoleh gaji yang tinggi, seorang pendidik ada yang rela meninggalkan negara yang telah membesarkannya untuk pindah ke negara lain karena dibayar oleh negara lain dengan gaji yang besar. Seorang pendidik yang bijaksana adalah orang yang melihat bahwa ilmu yang melekat pada dirinya adalah ilmu yang harus dibagikan kepada orang yang membutuhkan tanpa melihat pamrih atas ilmu yang diajarkan tersebut.

Ketujuh, jika seorang pendidik melakukan pekerjaan yang benar dan dibolehkan namun dalam satu kondisi yang sama, secara lahiriah hukumnya haram atau makruh atau dapat merendahkan harga diri dan sebagainya, maka semestinya ia memberitahukannya kepada para sahabatnya atau orang yang melihat perbuatannya tersebut agar mereka tidak berprasangka buruk dan melihat sisi positif dari keputusannya tersebut. Dengan memberitahukan mereka, maka orang lain tidak akan menjauhinya bahkan dapat mengklarifikasinya. ${ }^{24}$ Contoh kasus dalam hal ini misalnya tentang seorang pendidik yang terlibat suatu masalah yang membingungkan dirinya sehingga kalau masalah tersebut tidak diceritakan atau diberitahu kepada temannya niscaya masalah itu akan terjadi kesalahpahaman. Sebagai contoh seorang pendidik yang disuap untuk memberikan nilai bagus kepada salah seorang peserta didik, yang apabila ia tidak melaksanakannya, maka ia akan dikeluarkan dari sekolah tersebut. Jika masalah ini membingungkannya, maka pendidik tersebut dapat mendiskusikan dengan teman-temannya untuk memperoleh solusi yang terbaik. Sebaliknya, kalau persoalan ini dirahasiakan, maka teman dan orang yang ada di sekelilingnya akan mencurigainya.

\section{Etika Pendidik dalam Kegiatan IImiah}

Imâm al-Nawawî memaparkan bahwa seorang pendidik harus selalu aktif dalam menggali ilmu baik dengan kegiatan membaca, meneliti, melakukan observasi, memberikan

beda. Meskipun perak dan emas berasal dari saripati batuan, tetapi tidak semua batu mengandung emas dan perak." Mehdi Nakosteen, Kontribusi Islam atas Dunia Intelektual Barat: Deskripsi Analisis Abad Keemasan Islam (Surabaya: Risalah Gusti, 1996), h. 123.

${ }^{23}$ Al-Nawawî, al-Majmu' Syarah al-Muhazzab, h. 55.

${ }^{24} I b i d$. 
komentar sebuah tulisan, berdiskusi, maupun menghasilkan karya ilmiah berupa penyusunan buku. Tidak bersifat sombong terhadap orang lain karena merasa lebih senior atau lebih terkenal, maupun merasa sombong karena agama ataupun ilmu yang dimilikinya. Sebaliknya seorang pendidik itu harus selalu giat mencari manfaat (berdiskusi) dengan orang-orang yang berada di sekitarnya, meskipun orang-orang tersebut tidak memiliki apa yang dimilikinya. Sifat sportif juga harus ditunjukkan seorang pendidik itu dengan bertanya kepada siapapun terhadap ilmu yang tidak diketahuinya tanpa ada rasa malu dalam dirinya. Hal ini didukung oleh pernyataan Imam al-Nawawî yang mengatakan bahwa, "kami telah meriwayatkan dari 'Umar dan anaknya radhiallâh 'anhumâ, kedua sahabat ini pernah berkata, 'barang siapa yang tipis mukanya (pemalu), maka tipis pula (sedikit) ilmunya." 25 Argumentasinya tersebut juga diperkuat dengan pernyataan dari Sa'id ibn Jubair mengatakan bahwa "seseorang yang merasa memiliki ilmu kemuliaan meninggalkan aktivitas ilmiahnya tersebut dengan menyangka bahwa ia telah cukup memiliki ilmu yang ada padanya, maka ia itu adalah orang yang selalu berada dalam kebodohan."26

Imam al-Nawawî juga menyatakan bahwa seorang pendidik itu juga tidak boleh malu untuk bertanya kepada orang lain terhadap ilmu yang tidak diketahuinya, meskipun ia memiliki kedudukan yang tinggi dari orang yang lebih rendah kedudukannya. Para ulama Salaf juga sering bertanya kepada muridnya apa yang tidak mereka ketahui, bahkan para tabiin juga sering bertanya kepada tâbi tâbi în tentang sesuatu yang tidak mereka ketahui. ${ }^{27}$

Imam al-Nawawî menarik tujuh intisari dari sifat seorang pendidik dalam kegiatan ilmiahnya. Pertama, menjelaskan tentang sifat tawaduk dan menjelaskan bahwa seseorang itu lebih mulia apabila ia lebih banyak membaca daripada yang tidak suka membaca. ${ }^{28}$ Sebuah pepatah yang mengatakan bahwa buku itu adalah pintu ilmu dan membaca adalah kuncinya. Seorang pendidik yang baik adalah yang mengerahkan kemampuannya untuk selalu dan terus membaca. Karena setiap hari ia harus menyampaikan hal yang baru kepada setiap siswanya. Pendidik yang cerdas adalah yang mampu memberikan tambahan informasi yang terbaru kepada peserta didik yang diajarkannya. Di era informasi terkini dengan menjamurnya beragam fasilitas teknologi seperti internet, facebook, dan twitter ditambah dengan banyaknya muncul beragam gadget membuat orang malas membeli buku karena harus membeli dengan harga dan informasi yang dibutuhkan juga sering tidak diperoleh dengan lengkap. Berbeda dengan internet dalam hitungan detik dan dengan satu jari seluruh informasi yang dibutuhkan dapat diakses dengan mudah dan lengkap. ${ }^{29}$

Kedua, keharusan seorang pendidik untuk terus menuntut ilmu meskipun harus mengeluarkan banyak biaya. Seorang pendidik juga harus meminimalisir kegiatan yang

${ }^{25}$ Ibid., h. 56.

${ }^{26}$ Ibid.

${ }^{27}$ Ibid.

${ }^{28}$ Ibid.

${ }^{29}$ Murip Yahya, Profesi Tenaga Kependidikan (Bandung: Pustaka Setia, 2013), h. 78. 
tidak berhubungan dengan keilmuan meskipun waktu yang digunakan untuk melakukan hal lain tersebut dilaksanakan setelah ia melaksanakan kewajibannya dalam bidang keilmuan. ${ }^{30}$ Dalam praktiknya, seorang pendidik harus terus melanjutkan pendidikan akademisnya sampai ke jenjang yang paling tinggi dan rajin mengadakan penelitian untuk mendapatkan keahlian dalam bidang ilmu yang ditekuninya. Merasa cukup dengan pendidikan yang diperoleh merupakan tanda kemunduran dari pengetahuannya. Dalam dunia pendidikan tinggi, praktik semacam ini dikenal dengan nama Tridharma Perguruan Tinggi. ${ }^{31}$

Ketiga, seorang pendidik harus mengerahkan seluruh kemampuannya untuk menghasilkan karya ilmiah sesuai dengan keahliannya (spesialisasinya), agar terpancar hakikat-hakikat ilmu dan dapat dituangkan secara rinci ilmu itu agar terasa mantap dan kuat dalam dirinya, karena sesungguhnya seorang pendidik itu diharuskan banyak melakukan diskusi, penelitian, observasi, melakukan editing atas karya-karya ulama sambil menelaah berbagai perbedaan pendapat para ulama dan fukaha untuk menjelaskan secara jelas perbedaan yang menjadi sebuah masalah, menbenarkan pendapat yang dianggap lemah, menguatkan pendapat yang benar dari pendapat yang tidak benar. Seorang editor harus bersifat sebagai seorang mujtahid. ${ }^{32}$ Keunggulan ulama ataupun ilmuwan pada masa lalu adalah kehebatan mereka dalam menulis berbagai karya dalam berbagai cabang keilmuan. Ibn Rusyd (w. 1198 M) adalah seorang dokter yang multidisipliner, ia juga seorang filsuf, fukaha, dan hakim, sehingga ia dapat melahirkan karya dari berbagai bidang yang ditekuninya. Di antara buku yang ia tulis Tahâfut al-Tahâfut, sebuah karya filsafat yang menjawab kegalauan al-Ghazâlî (w. 505 H/ 1111 M) terhadap filsafat. Karyanya yang lain adalah Bidâyah al-Mujtahid yang merupakan kitab fikih yang berisi kompilasi pendapat empat mazhab yang diijtihadkannya berdasarkan sudut pandangnya. Berbeda dengan ilmuan di dunia modern, adanya spesialisasi dalam bidang keilmuan menyebabkan terkotaknya pemikiran dalam satu frame ilmu saja. Kegairahan menulis terkadang terpaksa muncul karena dikejar kewajiban untuk syarat kenaikan pangkat atau untuk memperoleh tunjangan atas kewajibannya.

Keempat, seorang pendidik jangan menulis karya ilmiah atas bidang pengetahuan yang tidak dikuasainya, karena hal ini akan berdampak tidak baik terhadap agama, kehormatan dan perkembangan keilmuannya. Jangan menerbitkan buku yang ia tulis sendiri kecuali setelah ia pelajari, diteliti segala aspeknya, dan ia telaah secara berulang-ulang. Ia juga harus memperhatikan keefektifan ungkapan kalimat-kalimat yang dipaparkan dalam sebuah karangan sehingga tidak berulang-ulang. Jangan pula ia terlalu meringkas kalimat sehingga kurang dipahami makna yang dimaksud dan terasa sulit memahaminya. ${ }^{33}$ Terkadang karena keterbatasan tenaga pendidik, seorang pendidik yang tidak memiliki keahlian dalam bidang keilmuan yang digeluti terpaksa harus menulis sebuah buku demi membantu siswa dalam

\footnotetext{
${ }^{30}$ Al-Nawawî, al-Majmu' Syarah al-Muhazzab, h. 56.

${ }^{31}$ Yahya, Profesi Tenaga Kependidikan, h. 80.

${ }^{32}$ Al-Nawawî, al-Majmu' Syarah al-Muhazzab, h. 56.

${ }^{33} I b i d .$, h. 57.
} 
proses belajarnya. Namun kenyataan bahwa disiplin ilmu tersebut tidak dikuasainya sehingga membuat isi buku pelajaran menjadi tidak dapat dipahami. Terlebih lagi kalau penulisan buku itu ditujukan untuk memperoleh uang dari penjualan kepada peserta didik.

Kelima, seorang pendidik yang menulis sebuah buku seharusnya tidak langsung menerbitkannya sebelum ia melakukan editing/penyuntingan naskah, meneliti kesalahannya, membacanya berulang-ulang agar dapat memperbaiki kesalahan yang ada dalam buku tersebut. ${ }^{34} \mathrm{Hal}$ ini sangat penting karena buku yang ditulis tidaklah luput dari kesalahan. Bahkan ada baiknya menyerahkan kepada tim khusus yang menangani pengeditan buku baik yang menyangkut isi maupun tata bahasanya. Tujuannya adalah agar buku yang akan dijadikan bagi peserta didik adalah buku yang dapat dipahami dan dipelajari dengan benar. Dalam pendidikan modern, dikenal istilah buku ajar atau bahan. Bahan atau buku ajar merupakan komponen pembelajaran yang paling berpengaruh terhadap apa yang sesungguhnya terjadi pada proses pembelajaran. Banyak pendidik yang mengajar sematamata mengikuti urutan penyajian dan kegiatan-kegiatan pembelajaran (teks) yang telah dirancang oleh penulis buku ajar tanpa melakukan adaptasi yang berarti. ${ }^{35}$

Keenam, dalam menjelaskan sesuatu mesti dalam bahasa yang lugas dan mudah dimengerti agar terbuka pemahaman orang yang mendengarnya dan jangan dengan bahasa yang singkat dan sulit dimengerti karena hal itu akan menambah kebodohan dan tertutupnya pintu pemahaman. ${ }^{36}$ Nabi Muhammad SAW. ketika berada di masjid bersama para sahabat selalu mengulang materi pelajaran yang baru atau subjek baru pada mereka dengan diulang tiga kali. Nabi Muhammad SAW. berbicara dengan bahasa yang mudah dicerna pendengarnya (wa khâthib al-nâs 'alâ qadri 'uqlihim). Selanjutnya Nabi meminta murid-muridnya yaitu para sahabat untuk mensosialisasikan apa yang mereka dengar pada orang-orang yang tidak hadir meskipun satu ayat "balligh 'annî walau âyah." Betapa tingginya dunia pendidikan di masa Nabi Muhammad SAW. hingga 'Ali ibn Abi Thâlib mengatakan anâ 'abd man 'allamanî-arfân (saya adalah hamba sahaya seseorang yang mengajarkan satu huruf). Nabi SAW. menyebut dirinya sebagai city of knowledge (madînat al-ilm, kota pengetahuan) dan 'Ali ibn Abi Thâlib sebagai gate of knowledge (bâb al-'ilm, pintu ilmu). Bahkan wahyu pertama turun ditandai dengan inti kegiatan intelektual yaitu membaca. Ada dua elemen yang membuat seseorang mampu membaca yaitu bashar yang berarti penglihatan mata, dan bashîrâ yang berarti kekuatan persepsi sikap mental atau accuteness of mind, kearifan intelegensia. Kekuatan yang terakhir lebih ampuh dari kekuatan pertama. Sementara kekuatan pertama terbatas pada dimensi ruang dan waktu dan sering tertipu oleh kekinian, dan kekuatan kedua mampu membawa seseorang ke tingkat yang lebih tinggi. ${ }^{37}$

\footnotetext{
${ }^{34}$ Ibid.

${ }^{35}$ Heri Gunawan, Pendidikan Karakter Konsep dan Implementasi (Bandung: Alfabeta, 2012), h. 226.

${ }^{36}$ Al-Nawawî, al-Majmu' Syarah al-Muhazzab, h. 57.

${ }^{37}$ Abdurrahman Mas'ud, "Pendidikan dan Ilmu Pengetahuan dalam Islam," dalam Paradigma Pendidikan (Yogyakarta: Pustaka Pelajar, 2001), h.9.
} 
Ketujuh, seorang pendidik itu harus mengarang sebuah buku dengan ketentuan sebagai berikut. (1) Buku tersebut harus lebih lengkap dari buku lain yang sama. Artinya, buku tersebut harus membahas sisi lain dari buku yang ditulis sebelumnya bukan termasuk edisi revisi. (2) Apabila buku yang dikarang adalah buku yang sama dengan pengarang yang lain, maka buku itu harus memuat berbagai macam informasi yang baru dan berbeda dari buku yang dianggap sama tersebut atau melengkapi informasi yang dianggap masih kurang. Hal ini dimaksudkan untuk menghindari plagiasi. Plagiasi merupakan tindakan yang melanggar hak cipta seseorang. ${ }^{38}$ Imam al-Nawawî menulis tentang Âdâb al-Alim wa al-Muta'allim, dan Ibn Jamâ'ah juga menulis kitab dengan judul yang sama. Meskipun memiliki kesamaan judul, namun antara Imam al-Nawawî memiliki pemikiran tersendiri tentang etika seorang pengajar dan pelajar. Munculnya penulisan sebuah buku biasanya dilatarbelakangi oleh faktor sosial yang terjadi pada masa buku tersebut ditulis. Buku tersebut harus memuat informasi yang bersifat umum dan menjadi sumber rujukan yang dibutuhkan dan meliputi sebagian besar ilmu.

\section{Etika Pendidik dalam Penyampaian Pelajaran}

Imam al-Nawawî menyatakan bahwa pengajaran itu merupakan pondasi dari tiang agama karena melalui pengajaran, maka kebodohan akan sirna dan ini menjadi prioritas agama serta ibadah yang paling agung. Hal ini juga merupakan fardh kifâyah yang sangat penting. ${ }^{39}$ Berikut ini adalah pandangan Imam al-Nawawî tentang etika pendidik dalam penyampaian pelajarannya.

Pertama, dalam menyampaikan pelajaran seorang pendidik harus berniat sematamata karena Allah dan jangan pernah menanamkan niat dalam hati bahwa mengajar menjadi perantara dalam mendapat hasrat duniawi. Seorang pendidik harus menghadirkan dalam pikirannya bahwa kegiatan pengajaran itu adalah ibadah yang paling penting agar menjadi motivasi yang kuat untuk memperbaiki niat dan berusaha menjaganya dari halhal yang dibenci, berusaha menghindari diri dari hal-hal yang dapat menyebabkan hilangnya keutamaan ilmu dan kebaikan bagi dirinya. ${ }^{40}$ Sikap seorang pendidik juga harus menunjukkan sikap kasih sayang kepada peserta didiknya, seperti kasih sayang seorang bapak atau ibu terhadap anak-anaknya sendiri. Sikap kasih sayang ini sangat perlu dimiliki oleh pendidik dalam mengembangkan proses belajar yang menyenangkan sehingga para peserta didik merasa aman, nyaman dan menyenangkan ketika ia masuk kelas, dan diterima dengan sepenuh hati oleh mereka mengajar dengan kasih sayang juga akan memunculkan sikap tulus dalam mengajar. Selain itu, ia akan disegani oleh peserta didik bukan ditakuti. ${ }^{41}$

\footnotetext{
${ }^{38}$ Al-Nawawî, al-Majmu' Syarah al-Muhazzab, h. 57.

${ }^{39}$ Ibid.

${ }^{40}$ Al-Nawawî, al-Majmu' Syarah al-Muhazzab, h. 57.

${ }^{41}$ B. Joice dan M. Weil, Model of Teaching (New Jersey: Englewood Cliffs Publisher, 1980),
} h. 188 . 
Kedua, seorang pendidik tidak boleh malas mengajar seseorang karena orang tersebut tidak memiliki niat yang lurus. Justru sebaliknya, ia harus memberikan pelajaran kepadanya dengan harapan ia dapat meluruskan niatnya tersebut. Bisa jadi seorang anak itu belum mampu memiliki niat yang baik sebagaimana orang dewasa karena belum memiliki kematangan emosi dan kurangnya minat untuk belajar dengan niat yang tulus. Keengganan mengajarkan orang-orang seperti ini akan menyebabkan ia tidak memperoleh ilmu sama sekali, diharapkan dengan diberikan kesempatan untuk belajar, ia akan mendapatkan keberkatan ilmu itu dan ia akan dapat meluruskan niatnya dan jadi berminat dengan ilmu tersebut. Ilmu itu milik Allah, Allah berhak merubah dan membuat ilmu itu jadi diminati. ${ }^{42}$ Pernyataan ini senada dengan yang diungkapkan Ibn Jamâ'ah dalam kode etik seorang ilmuwan bergaul dengan peserta didik. Ilmuwan tidak boleh berhenti mengajar peserta didik walaupun tujuan peserta didik tidak benar. Sebab, dengan belajar niatnya diharapkan dapat berubah lurus. Ibn Jamâ‘ah menyadari bahwa keikhlasan niat bukanlah sesuatu yang mudah, khususnya bagi peserta didik pemula. Karena itu ia menyarankan pendidik harus mengajar semua peserta didik, terlepas dari motivasi awal mereka menuntut ilmu. Namun pendidik harus mengupayakan perbaikan motivasi, dengan mengajarkan bahwa hanya dengan niat yang benar orang akan berhasil memperoleh keberkahan ilmu pengetahuan. Dengan niat yang benar pula hati bisa terbuka menerima rahasia ilmu dan kebijaksanaan yang mengantarkan pada derajat yang tinggi, di dunia maupun di akhirat. Ibn Jamâ‘ah meletakkan pendidikan sebagai proses pembinaan dan pembimbingan peserta didik ke arah lebih baik. Karena itu, titik mula orang bisa tidak ideal, tetapi bukan alasan menolaknya sebagai peserta didik. ${ }^{43}$

Ketiga, seorang pendidik itu harus mengajar para peserta didiknya berdasarkan tahapan dan proses dengan memperhatikan unsur etika, kepribadian yang terpuji, melatih pribadi para peserta didiknya agar beretika dan memiliki rasa tanggung jawab yang tinggi terhadap ilmunya, baik dalam bentuk yang abstrak maupun yang konkrit. Allah akan memberkahi segala pekerjaan, ilmu, dan sinerginya antara perbuatan dan perkataan dan kebijaksanaan, hidup penuh kesederhanaan, terhindar dari ketergantungan kepada dunia dengan meyakini bahwa segala yang ada itu sifatnya binasa (fana), sedangkan akhirat yang akan datang itu adalah kekal. ${ }^{44}$

Keempat, seorang pendidik harus memotivasi para siswanya tentang pentingnya ilmu serta keutamaan yang melekat pada ilmu tersebut. Selain itu, memotivasi agar mengikuti langkah-langkah yang ditempuh para ulama karena mereka itu adalah pewaris para nabi yang tidak ada lagi tingkatan yang paling tinggi dari para nabi. ${ }^{45}$

\footnotetext{
${ }^{42}$ Al-Nawawî, al-Majmu' Syarah al-Muhazzab, h. 57.

${ }^{43}$ Badr al-Dîn Ibn Jamâ'ah, Tazkirah al-Sâmiwa al-Mutakallim fîÂAâb al-'Âlim wa al-Muta'allim, diedit oleh 'Abd al-Amîr Syams al-Dîn (Beirut: Dâr Iqrâ', 1986), h. 98.

${ }^{44}$ Al-Nawawî, al-Majmu' Syarah al-Muhazzab, h. 58.

${ }^{45}$ Ibid.
} 
Kelima, seorang pendidikharusmemilikikelembutan danmencurahkan segalakemampuannya demi membangun kemaslahatan sebagaimana kemaslahatan untuk diri dan anaknya. Seorang pendidik harus menyayangi peserta didiknya sebagaimana ia menyayangi anakanaknya dengan penuh kebaikan. Seorang pendidik juga dituntut untuk bersikap sabar atas tingkah laku mereka yang tidak patuh dan tidak sopan. Memberikan hukuman atas perilaku tidak baik atau kasar yang mereka lakukan sesekali waktu dengan tujuan agar mereka menyadari kesalahannya. ${ }^{46}$

Keenam, seorang pendidik harus mencintai murid-muridnya sebagaimana ia mencintai dirinya sendiri dalam hal kebaikan, dan membenci keburukan sebagaimana ia juga membencinya. ${ }^{47}$

Ketujuh, seorang pendidik harus bersikap lapang dada (terbuka) dalam menyampaikan ilmunya, sederhana dan mudah dipahami sehingga peserta didik dapat mengambil manfaat ditambah lagi dengan nasihat yang lembut dan mau menunjukkan kepada hal-hal yang penting bagi mereka, memotivasi mereka untuk selalu menjaga apa yang menjadi kekuatan pribadi dan manfaat bagi kematangan jiwa. ${ }^{48}$

Kedelapan, seorang pendidik tidak boleh menyembunyikan dari para peserta didiknya ilmu yang ingin diketahui oleh mereka, meskipun mereka tersebut sudah pernah mempelajarinya atau ahli dalam bidang studi itu. Namun, janganlah seorang pendidik memberikan ilmu kepada orang yang tidak mampu untuk menerimanya agar ilmu tersebut tidak mendatangkan kerusakan kepada peserta didik tersebut. Jika mereka tetap menanyakan hal itu, maka janganlah seorang pendidik tersebut menjawabnya. Hendaklah ia memberikan pengertian kepada peserta didik tersebut, bahwa hal itu akan berakibat buruk pada dirinya dan tidak akan mendatangkan manfaat. Hal itu tidak akan menjadikan dirinya disebut orang yang kikir, justru sikap tersebut menunjukan sifat kasih sayang dan kelembutan kepada para peserta didiknya. ${ }^{49}$

Kesembilan, seorang pendidik tidak boleh merasa ta'zhîm (harus dihormati) terhadap para peserta didiknya, namun sebaiknya ia harus bersikap tawahuk dan lemah-lembut. ${ }^{50}$

Kesepuluh, seorang pendidik harus bersemangat dalam memberikan materi pelajaran dan konsentrasi dengan apa yang diajarkannya agar memberikan pengaruh yang signifikan terhadap kebutuhan pelajar dan memberi maslahat pada dirinya selama tidak merugikan, dan memberikan sambutan yang hangat kepada mereka, dan menunjukkan kepada mereka wajah yang selalu gembira dan memperlakukan mereka dengan baik, dan jangan berbicara dengan mereka menggunakan namanya tetapi pakailah kuniyah-nya (panggilan yang hormat). ${ }^{51}$
${ }^{46}$ Ibid.
${ }^{47} \mathrm{Ibid}$.
${ }^{48}$ Ibid.
${ }^{49}$ Ibid.
${ }^{50} \mathrm{Ibid}$.
${ }^{51} I b i d .$, h. 59. 
Kesebelas, seorang pendidik harus menanyakan ketidakhadiran peserta didiknya dan mencari sebab ketidakhadirannya tersebut. ${ }^{52}$

Keduabelas, seorang pendidik harus mengerahkan usahanya untuk memberikan pemahaman yang mudah dan memberikan faedah kepada para peserta didiknya sehingga kemampuan akal mereka dapat menangkap apa yang disampaikan oleh para pendidiknya untuk selanjutnya mereka dapat menghapalkannya. Janganlah menyampaikan ilmu yang tidak sanggup mereka memahaminya begitu juga jangan terlalu singkat sehingga mereka tidak mengerti isi materi pelajaran tersebut. Bicaralah dengan ungkapan-ungkapan bahasa yang sesuai dengan taraf pengetahuan mereka, gunakan kalimat-kalimat yang mudah dipahami. Bagi peserta didik yang kurang berkonsentrasi, maka berilah pengulangan sampai ia bisa menghapalkannya. Memberikan contoh atas materi yang sifatnya abstrak agar ia dapat memahaminya dengan mudah dan cepat. ${ }^{53}$

Ketigabelas, menjelaskan garis-garis besar pelajaran dan memberikan catatan untuk pelajaran usul fikih dan menyusun dalil-dalil dari kitab al-Qur'an, hadis, ijmak, kias, dan istish $\underline{h} \hat{a} b . .^{54}$

Keempatbelas, jika seorang pendidik menghadapi suatu masalah yang sulit dan rumit atau ditanya tentang hal-hal yang sepele (biasa), maka ia harus menjelaskan pertanyaan tersebut. Dalam hal menerangkan pelajaran harus setahap demi setahap agar mereka mampu mengumpulkan ilmu yang mereka dapat sesuai dengan masa belajarnya dengan catatan yang banyak..$^{55}$

Kelimabelas, seorang pendidik harus terus mengerahkan pikirannya setiap waktu untuk mengajar, merencanakan waktu yang tepat agar para siswanya mengulangi pelajaran dan hapalan mereka dan memberikan pertanyaan tentang hal-hal yang dianggap penting dari ingatan mereka. Apabila di antara peserta didik itu ada yang mampu mengingat dengan baik dan dapat menjawab pertanyaan dengan benar, maka seorang pendidik boleh memberinya hadiah berupa pujian dan menyiarkan kepada teman-temannya selama pujian tersebut tidak menjerumuskan peserta didik ke dalam penyakit 'ujub. Sedangkan bagi yang belum mampu menjawab pertanyaan dan mengingat hapalan diberikan kesempatan untuk mengulanginya sampai benar-benar dapat dan jangan diberikan hukuman atau menjauhinya. ${ }^{56}$

Keenambelas, seorang pendidik seharusnya mendahulukan kelompok belajar yang terlebih dahulu datang apabila terdapat beberapa kelompok belajar yang jam pelajarannya diberlakukan secara bergantian. Materi pelajaran juga harus disesuaikan dengan waktu yang ditetapkannya. Artinya, kelompok pertama harus memiliki jam belajar yang sama

\footnotetext{
${ }^{52}$ Ibid.

${ }^{53}$ Ibid.

${ }^{54}$ Ibid.

${ }^{55}$ Ibid., h. 61.

${ }^{56} I b i d .$, h. 62.
} 
dengan kelompok yang menunggu. Materi pelajaran yang disampaikan sebaiknya adalah materi yang pantas diterima oleh pemahaman mereka dengan metode yang paling mudah dimengerti dalam penyampaian juga harus lugas dan jelas. ${ }^{57}$

Ketujuhbelas, dalam menyampaikan materi seorang pendidik juga harus bersedia memberi baris huruf dan menjelaskan makna dan lafaz yang dianggap sulit kecuali jika ia meyakini bahwa seluruh pelajarnya memahami makna dan lafaz kalimat tersebut tanpa diberi penjelasan. Namun apabila ia merasa penjelasannya belum sempurna atau lengkap kecuali dengan menjelaskan sebuah kalimat yang dianggap tabu oleh masyarakat, maka sebutkan saja kalimat tersebut dengan jelas. Jangan menganggap hanya karena malu mengungkapkan sebuah kalimat yang dianggap tabu atau hanya karena untuk memelihara etika penjelasan menjadi tidak lengkap. ${ }^{58}$

Kedelapanbelas, dalam hal penampilan, seorang pendidik harus duduk dalam posisi yang berwibawa dan memakai pakaian yang putih lagi bersih, jangan memakai pakaian karena berniat bangga dengan pakaiannya dan jangan pula memakai pakaian yang tidak layak sehingga banyak orang yang menganggapnya orang yang tidak punya kehormatan. Memiliki etika yang baik ketika duduk di tengah para peserta didiknya, memuliakan orang karena ilmu dan usianya, kemuliaan atau berbuat kemaslahatan, bersikap lembut dengan orang lain, menghormati majelis tempat berkumpulnya orang-orang yang mulia, memuliakan mereka dengan berdiri sebagai penghormatan kepada mereka. Tidak dibolehkan berdiri kepada orang yang tidak layak diberikan penghormatan. ${ }^{59}$

Kesembilanbelas, menjaga dirinya dari berbagai macam kotoran, menjaga mata dengan cara menghindari penglihatan dari segala yang tidak penting. Ketika berbicara di hadapan orang banyak, maka pandanglah ke arah mereka agar mereka merasa dihargai. ${ }^{60}$

Keduapuluh, Imam al-Nawawî menjelaskan bahwa seorang pendidik harus duduk di tempat yang tinggi agar pendengar atau orang yang belajar dapat dengan jelas melihat wajah pendidiknya. ${ }^{61}$

Keduapuluhsatu, sebelum pelajaran dimulai seorang pendidik haruslah terlebih dahulu membaca beberapa ayat al-Qur'an, bismillâh, tahlmîd dan berselawat kepada Nabi Muhammad SAW. dan keluarganya, selanjutnya dipanjatkan juga doa untuk para ulama terdahulu baik pendidiknya, orang tuanya dan para hadirin serta seluruh kaum Muslim. ${ }^{62}$

Keduapuluhdua, seorang pendidik jangan menyampaikan pelajaran, sedangkan ia

${ }^{57} \mathrm{Ibid}$.
${ }^{58} \mathrm{Ibid}$.
${ }^{59} \mathrm{Ibid}$.
${ }^{60} \mathrm{Ibid}$.
${ }^{61} \mathrm{Ibid}$.
${ }^{62} \mathrm{Ibid}$. 
sendiri dalam kondisi yang tidak sehat dan menganggu konsentrasinya, seperti sakit, lapar atau ingin membuang hajat atau terlalu gembira atau sebaliknya terlalu sedih. ${ }^{63}$

Keduapuluhtiga, jangan terlalu lama dalam menyampaikan pelajaran sehingga membuat pelajar menjadi bosan atau membuat pelajar itu susah untuk memahami pelajaran yang lain, bahkan susah untuk menghapalnya, karena sesungguhnya belajar itu bertujuan untuk memberikan manfaat untuk pengetahuan dan hapalan mereka. Apabila hal ini terjadi, maka tujuan dari belajar itu akan hilang. ${ }^{64}$

Keduapuluhempat, seorang pendidik harus bisa menjadikan ruang kelas menjadi tempat yang menyenangkan, jangan menerangkan dengan suara yang sangat keras, dan jangan pula dengan suara yang sangat pelan sehingga pelajaran yang diterima kurang maksimal. ${ }^{65}$

Keduapuluhlima, ruangan kelas harus terhindar dari keributan dan hiruk pikuk, pelajar juga harus menjaga dirinya dari etika yang tidak baik ketika pelajaran berlangsung, apabila salah seorang dari mereka menunjukkan etika yang tidak baik, maka berilah peringatan kepada mereka dengan lemah lembut sebelum mereka pergi meninggalkan kelas. ${ }^{66}$

Keduapuluhenam, apabila salah seorang bertanya tentang sesuatu yang aneh, maka teman yang lain tidak boleh menyepelekan teman yang bertanya itu. Apabila pendidik itu ditanya tentang sesuatu yang tidak diketahuinya atau keluar dari materi yang sedang dipelajari, sedangkan ia tidak mengetahui jawabannya, maka katakanlah "saya tidak tahu" atau "saya tidak yakin," dan janganlah ia merasa sombong dengan mengarang jawaban. Di antara sifat orang yang berilmu itu, apabila ia tidak mengetahui jawaban pertanyaan, ia akan menjawab "saya tidak tahu, atau Allâhu a lam (Allah Maha Tahu)." Ibn Mas'ud mengatakan "seseorangyang mengetahui jawaban sebuah pertanyaan, makajawablah pertanyaan itu, namun jika ia tidak mengetahui jawabannya, maka katakanlah bahwa ia tidak tahu, atau katakanlah Allah Maha Tahu. Dianjurkan setelah menjelaskan sesuatu ataupun menjawab sebuah pertanyaan, maka sertakanlah di akhir perkataan dengan kalimat 'wallahualam"'. ${ }^{67}$

Keduapuluhtujuh, orang yang berilmu/seorang pendidik itu harus berani dan jujur mengatakan bahwa saya tidak tahu kepada sahabatnya, apabila ia memang tidak tahu. Ungkapan kejujuran ini tidak akan membuat harga diri dan kedudukannya menjadi rendah. Sebaliknya, hal ini menunjukkan kebesaran hatinya dan ketakwaannya, selain itu juga menunjukkan kesempurnaan pengetahuannya. ${ }^{68}$

Keduapuluhdelapan, seorang pendidik itu harus melaporkan kepada para sahabatnya/

\footnotetext{
${ }^{63}$ Ibid., h. 63.

${ }^{64} \mathrm{Ibid}$.

${ }^{65}$ Ibid.

${ }^{66}$ Ibid.

${ }^{67}$ Ibid.

${ }^{68}$ Ibid.
} 
koleganya, ketika ia menghadapi sebuah masalah yang pelik dan meminta pendapat mereka sesuai dengan kepakarannya dan sesuai dengan ilmu yang mereka kuasai serta mengutamakan pendapat yang benar-benar memberikan keunggulan, tidak segan memberikan penghargaan kepada mereka yang benar-benar berprestasi agar ia menjadi semangat mengadakan penelitian ilmiah dan rajin berlatih sampai mereka terbiasa melakukannya, dan janganlah berlaku kasar apabila mereka membuat kesalahan, kecuali kekerasan-kekasaran yang dilakukan itu dapat membuatnya menjadi lebih baik. ${ }^{69}$

Keduapuluhsembilan, apabila masa belajar dan penyampaian materi telah selesai, maka seorang pendidik harus meminta para peserta didiknya mengulangi apa yang telah dipelajari, agar apa yang telah dipelajari dapat menguatkan hapalan dan memperdalam pengetahuan mereka. Namun, apabila mereka mendapat kesulitan tentang materi yang diulang tersebut, seorang pendidik haruslah menjelaskannya kembali. ${ }^{70}$

Ketigapuluh, memperbaiki niatagar tidak terjerumus ke dalam kelalaian dan ketidaktahuan. Jika didapati seorang pendidik yang fasik, selalu membuat bidah atau sering membuat kesalahan, maka menghindarlah agar terhindar dari kekeliruan. ${ }^{71}$

\section{Relevansi Teori al-Nawawî dengan Pendidikan di Indonesia}

Imam al-Nawawî adalah seorang tokoh intelektual Islam yang sangat terkenal dengan kedalaman ilmunya khususnya pada bidang ilmu fikih dan usul fikih. Di sisi lain, tidak berlebihan jika dikatakan bahwa ia sebagai tokoh pendidikan Islam. Hal ini dapat ditelusuri melalui aktivitasnya sebagai seorang pendidik (syaikh) di beberapa lembaga pendidikan Dâr al- $\underline{\text { Hadîts. }}$.

Berdasarkan pemaparan teori-teori Imam al-Nawawî tentang etika seorang pendidik, maka dapat diketahui relevansi dari teori-teori Imam al-Nawawî khususnya tentang etika seorang pendidik dengan pendidikan Islam di Indonesia. Pertama, teori-teori Imam al-Nawawî tentang etika personal atau yang berkaitan dengan diri sendiri kelihatannya sangat relevan untuk dijadikan sebagai bahan rujukan guna melengkapi kompetensi-kompetensi yang sudah ditetapkan pemerintah dalam undang-undang sebagai syarat profesional. Dalam kompetensi kepribadian, ada beberapa kriteria yang harus dipenuhi sebagai seorang pendidik. Kompetensi kepribadian adalah kemampuan personal yang mencerminkan kepribadian yang mantap, stabil, dewasa, arif, dan berwibawa, menjadi teladan bagi peserta didik, dan berakhlak mulia. Ia telah memaparkan bagaimana seorang pendidik mampu bersikap ikhlas, dan jujur, dan cara-cara meraih sifat-sifat tersebut. Hal ini menandakan bahwa teori-teori yang dipaparkan Imâm al-Nawawî dapat berkontribusi terhadap pembinaan kompetensi para pendidik di era modern.

\footnotetext{
${ }^{69}$ Ibid.

${ }^{70} \mathrm{Ibid}$.

${ }^{71} I b i d .$, h. 64.
} 
Kedua, teori-teori Imam al-Nawawî yang berkaitan dengan etika seorang pendidik dalam menyampaikan pelajarannya. Hal ini berkaitan dengan interaksi antara pendidik dengan peserta didik. Ia memaparkan bahwa di antaranya seorang pendidik harus menganggap para peserta didiknya seperti anak kandungnya sendiri. Prinsip ini sungguh menggambarkan kedekatan dan kesungguhan dalam memberikan ilmu kepada para peserta didiknya. Jika prinsip ini dibangun, maka tidak akan ada lagi seorang pendidik yang memperlakukan peserta didiknya dengan tidak senonoh. Prinsip ini sungguh sangat relevan dengan kondisi di zaman sekarang ini. Sikap ini dapat terealisasi dengan niat yang ikhlas yang bermuara kepada Sang Pencipta, yaitu Allah SWT.

Ketiga, teori-teori Imam al-Nawawî yang berkaitan dengan etika seorang pendidik dalam kegiatan ilmiahnya. Teorinya ini sungguh sangat relevan dengan kondisi di zaman sekarang ini. Di antaranya kewajiban sebagai dosen misalnya dalam melahirkan karya ilmiahnya. Ia memaparkan bahwa seorang pendidik harus menulis karya ilmiah sesuai dengan latar belakang keilmuannya (spesialisasinya), inilah yang menandakan seseorang tersebut layak disebut sebagai seorang ilmuwan. Seorang pendidik tidak boleh menulis karya ilmiah yang sama dengan pengarang yang lain. Jika ada kesamaan, maka buku itu harus memuat berbagai macam informasi yang baru dan berbeda dari buku yang dianggap sama tersebut atau melengkapi informasi yang dianggap masih kurang. Hal ini dimaksudkan untuk menghindari plagiasi. Plagiasi merupakan tindakan yang melanggar hak cipta seseorang. Ini jelas sangat relevan dengan kondisi zaman sekarang ini. Dengan demikian, teoriteori Imâm al-Nawawî ini layak untuk dijadikan bahan rujukan dalam menciptakan etika akademis yang jujur dalam aktivitas ilmiahnya.

\section{Penutup}

Berdasarkan kajian terdahulu, dapat disimpulkan bahwa peradaban Islam memiliki khazanah karya akademik yang sangat karya. Dalam bidang etika akademik, sebagian ulama telah menghasilkan karya-karya mengenainya. Para ulama yang menulis dalam tema dimaksud tidak saja yang menekuni bidang filsafat dan tasawuf, tetapi juga bidang hukum Islam. Dari kasus Imam al-Nawawî, seorang fukaha yang sangat masyhur, dapat dilihat betapa ia menilai penting kajian etika akademik dalam proses pembelajaran. Berdasarkan karyanya, ia menilai bahwa seorang pendidik, misalnya, harus memperhatikan etika personalnya sebagai pendidik, etika akademik dalam kegiatan ilmiahnya, dan etika akademik dalam menyampaikan pelajaran. Dari kajian di atas, dapat dilihat bahwa Imam al-Nawawî menilai bahwa seorang pendidik harus memperhatikan adab-adab dalam setiap segala aktivitasnya. Dalam karyanya, ia juga membahas etika akademik peserta didik, yang perlu diteliti oleh para peneliti lainnya. 


\section{Pustaka Acuan}

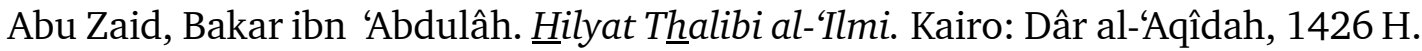

Alfan, Muhammad. Filsafat Etika Islam. Bandung: Pustaka Setia, 2011.

Al-Nawawî. Al-Majmu' Syarah al-Muhazzab. Beirut: Dâr al-Fikr, 1980.

Al-Zabîdî, Muhammad 'Abd al-Razzâk. Tâj al-Ars min Jawâhir al-Qâms, Vol I. Beirut: Dâr Ihyâ' al-Turâts, 1984.

Bertens, K. Etika, Cet. 10. Jakarta: Gramedia Pustaka Utama, 2007.

Gunawan, Heri. Pendidikan Karakter: Konsep dan Implementasi. Bandung: Alfabeta, 2012.

Ibn 'Asâkir, Abî al-Qâsim 'Alî ibn Husain ibn Hibah al-Allâh ibn 'Abd Allâh al-Syâfiî̀, Târîkh Madînah Dimasyq, ditahqiq oleh Muhibb al-Dîn Abî Sa'îd. Beirut: Dâr al-Fikr, 1415/ 1995.

Ibn al-Aththâr. Tuhfah al-Thâlibîn, Vol. III. Beirut: Dâr Ihyâ' al-Turâts, 1989.

Ibn Khaldûn, 'Abd al-Rahmân. Muqaddimah, Jilid II. Beirut: Dâr al-Jayl, t.t.

Ibn Jamâ'ah, Badr al-Dîn. Tazkirah al-Sâmi' wa al-Mutakallim fí Adab al-'Âlim wa alMuta'allim, diedit oleh 'Abd al-Amîr Syams al-Dîn. Beirut: Dâr Iqra', 1986.

Joice, B., dan M. Weil. Model of Teaching New. Jersey: Englewood Cliffs Publisher, 1980.

Kartanegara, Mulyadhi. Nalar Religius: Memahami Hakikat Tuhan, Alam dan Manusia Jakarta: Erlangga, 2007.

Langgulung, Hasan. Azas-Azas Pendidikan Islam. Jakarta: Pustaka al-Husna, 1987.

Mas'ud, Abdurrahaman. "Pendidikan dan Ilmu Pengetahuan dalam Islam," dalam Paradigma Pendidikan. Yogyakarta: Pustaka Pelajar, 2001.

Mustafa, A. Akhlak Tasawuf, Cet. 3. Jakarta: Pustaka Setia, 1999.

Nakosteen, Mehdi. Kontribusi Islam atas Dunia Intelektual Barat: Deskripsi Analisis Abad Keemasan Islam. Surabaya: Risalah Gusti, 1996.

Suseno, Frans Magnis. Etika Dasar: Masalah-Masalah Pokok Filsafat Moral. Yogyakarta: Kanisius, 1993.

Syâkir, Mahnmûd. Al-Târîkh al-Islâmî al-Ahdi al-Mamlukî, Jilid VII. Beirt: al-Maktabah alIslâmî, $1421 \mathrm{H}$.

Usman. "Karakter Pendidik di Era Klasik dan Modern: Sebuah Upaya Menuju Pendidik yang Berkualitas," dalam Suwito dan Fauzan (ed.) Sejarah Sosial Pendidikan Islam. Jakarta: Kencana, 2005.

Yahya, Murip. Profesi Tenaga Kependidikan. Bandung: Pustaka Setia, 2013. 